\title{
Aborto e infanticídio na Medicina: perturbações e desordens
}

\author{
Fabíola Rohden
}

\section{SciELO Books / SciELO Livros / SciELO Libros}

ROHDEN, F. Aborto e infanticídio na Medicina: perturbações e desordens. In.: A arte de enganar a natureza: contracepção, aborto e infanticídio no início do século XX [online]. Rio de Janeiro: Editora FIOCRUZ, 2003, pp. 47-88. História e saúde collection. ISBN: 978-65-5708-117-4. https://doi.org/10.7476/9786557081174.0004.

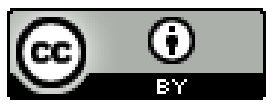

All the contents of this work, except where otherwise noted, is licensed under a Creative Commons Attribution 4.0 International license.

Todo o conteúdo deste trabalho, exceto quando houver ressalva, é publicado sob a licença Creative Commons Atribição 4.0.

Todo el contenido de esta obra, excepto donde se indique lo contrario, está bajo licencia de la licencia Creative Commons Reconocimento 4.0. 


\section{Aborto e Infanticídio na Medicina: perturbações e desordens}

Aborto e infanticídio são temas que mobilizam de maneira especial a atenção dos médicos na primeira metade do século $\mathrm{XX}$, principalmente de uma elite vinculada a instituições de destaque como a Academia Nacional de Medicina e a Faculdade de Medicina do Rio de Janeiro. Constantemente esses atores, ao lado também de juristas e outras figuras eminentes, se envolviam em importantes polêmicas públicas. Na medida em que aborto e infanticídio são debatidos repetidas vezes e em distintos contextos, revelam-se informações importantes a respeito dos métodos, agentes e questões relacionadas com a sua prática, sobretudo na cidade do Rio de Janeiro. Como será possível perceber, medicina e justiça se cruzam em várias discussões. É evidente que esta relação não se dá exclusivamente em torno dos temas aqui tratados. Porém, particularmente a categoria “loucura puerperal", assunto bastante caro aos médicos e freqüentemente evocado no sistema jurídico-policial, nos permite mapear a partir de um foco bastante singular os debates e os acordos entre médicos e juristas que tratavam da prática de aborto e infanticídio.

Em um trabalho de 1852 encontramos explicitadas algumas das razões que dão sentido à relação entre medicina e justiça, no que se refere aos supostos crimes cometidos pelas mulheres nas tentativas de controle do número de filhos. A tese de Luiz Corrêa de Azevedo Junior, A medicina legal da gravidez e do parto, ilustra como se gera um domínio particular, na fronteira entre a medicina legal e a ginecologia e obstetrícia, preocupado com os crimes ou delitos associados à gravidez e ao parto.

Assim como muitos outros autores, Azevedo Junior se pergunta a respeito das razões que pressionam uma mulher destinada a ser mãe a 
cometer atrocidades, especialmente contra os seus próprios filhos. Chega à conclusão de que o instinto materno, nesses casos, foi corrompido pelos avanços da civilização que levam a mulher a uma busca desenfreada da satisfação das suas vaidades e esquecimento dos deveres de mãe e esposa. Em virtude disso, é dever do médico tentar explicar e propor saídas para estas atitudes femininas 'antinaturais'. Particularmente, é à medicina legal que cabe esta função. No discurso do autor fica evidente a disputa entre médicos e juristas e a pretensão dos primeiros, devida ao fato de que dominariam toda a natureza: "O juiz interroga para surpreender na mentira; o médico interroga para assegurar-se da verdade. O juiz interroga como homem; o médico como um Deus. As leis escritas são da alçada do juiz; a natureza inteira é do Médico" (Azevedo Junior, 1852:6). Enquanto o juiz crê, o médico, cientista, examina, interroga e pensa.

O mundo acusa a mulher de haver matado o fruto de sua maternidade -é um crime, um crime horrendo! - Que fazer? O juiz não crê nas lágrimas sentidas daquela que se defende de monstruosa argüição; acode o médico; vê, examina, interroga e pensa; seus gestos, sua placidez, sua mudez é ansiosamente interrogada pela mãe que implora o perdão: o médico enfim dá a sentença quase divina, o juiz sanciona com a da humanidade.

Eis o médico no foro! (Azevedo Junior, 1852:8. Grifo do autor)

O médico é então o agente mais indicado para tratar e propor saídas aos delitos relacionados a sexo e reprodução cometidos pelas mulheres. Imbuído dessa missão, ele precisa estar consciente de que as mulheres podem mentir a respeito da existência de uma gravidez, por causa de diversas razões: por vício inerente à sua organização, por sedução, por querer aliar-se a um homem, por diversos estados patológicos do útero, para se apossar de uma herança ou nome, para não consentir no desquite, para acusar um inocente, por vício ou depravação de faculdades mentais etc. (Azevedo Junior, 1852:10). Essa lista mostra como, na concepção do médico, as mulheres poderiam se comportar de maneira doentia ou ardilosa no que se refere a uma gravidez, enganando maridos e mesmo médicos.

Ciente desse perigo, o médico chamado para diagnosticar uma gravidez, em particular em questões legais, deve orientar-se pela tentativa de responder a um conjunto de perguntas: Está a mulher em estado de conceber? Pode a mulher ignorar o seu estado de gravidez? Pode uma mulher grávida ter inclinações capazes de prejudicar a ordem social? Como 
reconhecer que uma mulher pariu recentemente? Qual é a época em que não é mais permitido distinguir traços de um parto recente? Pode uma mulher parir sem sabê-lo? O parto ocorre sempre em uma mesma época da gravidez ou há nascimentos tardios ou prematuros? É possível a superfetação, isto é, pode-se admitir que uma mulher que concebeu seja capaz de ser de novo fecundada, antes de expulsar o fruto da primeira concepção? (Azevedo Junior, 1852).

Para responder a estas perguntas o especialista deve considerar a idade, o estado e a moralidade da mulher. O clima pode também ser um fator importante, na medida em que se sabe que, nos climas quentes, ignorar o estado de gravidez é quase impossível, em contraste com os países de clima frio.

Tomai uma mulher moça de qualquer cantão da Suíça, ou das montanhas da Escandinávia ou dos vales da Finlândia, narcotizai-a, submeteia ao coito, e se ela conceber, talvez ignore durante alguns meses o seu estado. Pois bem, essa simplicidade de seus costumes a levará também a jamais carecer de ser submetida a um exame médico-forense. (Azevedo Junior, 1852:16)

O médico também deve saber que a gravidez influencia a moral da mulher, podendo levar à perversão, à perturbação da vontade, dos gostos, afetos e a paixões extravagantes. Em alguns casos pode-se falar mesmo em alienação. E um crime perpetrado por uma mulher grávida nesta condição deve ser atenuado ou mesmo absolvido. Moléstias originárias no útero podem levar a mulher, a mais honesta, a mais casta, à ninfomania. E este estado deplorável pode ser o verdadeiro responsável por crimes cometidos pelas mulheres grávidas.

O texto de Azevedo Junior é extremamente ilustrativo em um outro ponto, que se refere às razões do interesse da sociedade pela mulher grávida. Explica o autor:

O resultado da gravidez é o parto. A mulher que esteve grávida tem de necessariamente apresentar um filho, ou vivo ou morto.

No parto é a sociedade grandemente interessada para poder determinar as filiações e a sua legitimidade, porque delas dependem todas as relações do estado de família ou de cidade, e até às vezes de liberdade.

Nos partos a sociedade ou nenhum interesse tem com a parturiente, mas tem muito com o filho, cujo lugar pode desde logo ficar-lhe 
assinalado; ou então tem muito com a parturiente para o exame de seu estado. (Azevedo Junior, 1852:19)

Constata-se, assim, que a sociedade não está interessada a princípio na mulher, mas naquilo em que ela pode ser produtiva ou prejudicial. O que está em jogo é a produção de novos indivíduos para a coletividade. E a mulher que chegou ao estado de gravidez tem de necessariamente apresentar algum resultado, ou seja, o filho, mesmo que seja morto. A gravidez está muito longe de ser vista como um evento do plano pessoal ou privado. Ela é um acontecimento social, na medida em que deve ser de domínio público, mas também no sentido de que produz bens para a sociedade. A mulher tem como destino a reprodução. Desde a mais tenra idade e especialmente a partir da puberdade, ela passa a ser vigiada para que nada comprometa esta missão. Com a chegada da gravidez, este cuidado contínuo parece ser agravado. É o momento em que a mulher cumpre o seu destino e se converte de fato em um ser para a espécie, perdendo a qualidade de sujeito individual. E se no cumprimento desta missão algo sair errado, é preciso investigar muito bem as razões, determinando se se trata de um crime ou de uma manifestação de loucura.

A partir de 1877 começam a aparecer teses que tratam especificamente do fenômeno da loucura puerperal. A definição de Francisco C. de A. Franco (1877) esclarece que esse tipo de loucura não se refere apenas ao período após o parto. Segundo o autor, a loucura puerperal consiste nas perturbações mentais desenvolvidas durante a gestação, a parturição e a lactação. Acrescenta que, pelo menos desde François Mauriceau (em torno de 1740), já se falava da alienação mental das grávidas e paridas. E as estatísticas do momento comprovavam a extensão do mal. Esquirol teria diagnosticado, em quatro anos, 92 alienadas da Salpetrière sofrendo de loucura puerperal. Na sua clínica privada, eram 21 casos em 144 doentes. Entre 78 alienadas recolhidas ao estabelecimento do Dr. Eiras no Rio de Janeiro, no período em que escrevia a tese, Franco revela que cinco casos eram de loucura puerperal. O autor chega a concluir que, em média, uma em cada 12 ou 13 alienadas sofre deste tipo de perturbação (Franco, 1877).

Quanto às causas, Franco relaciona duas ordens de fatores. A primeira se refere às causas predisponentes. Nestas, estão incluídas a herança, a anemia, o grande número de partos, o estado moral da mulher (que sofre com as desordens provocadas pela gravidez), os acessos anteriores de loucura, a idade e o sexo do feto (quando fosse homem, a tendência à 
loucura seria maior). Na segunda ordem de fatores estão as causas ocasionais, como a ação simpática do útero, as emoções morais, a ação mecânica do útero (que produz o esmagamento de outras vísceras e o desequilibrio do organismo), a dor no parto, os lóquios e a lactação, a eclâmpsia e a albuminúria, a cloroformização e a chegada da primeira menstruação após o parto.

Na descrição da loucura puerperal, Franco se utiliza dos dados de Marcé sobre 16 doentes. Destas, dez apresentavam traços de melancolia. As outras seis eram maníacas. Entre as maníacas, em quatro casos a loucura se acompanhava de estupor, em um, havia viva excitação, em três, idéias de suicídio e em dois, alucinações. A partir destes exemplos, Franco explica que a loucura puerperal pode apresentar-se sob a forma de monomania, melancolia e mania. A primeira é a menos freqüente e se caracteriza por lesões parciais da inteligência. A segunda tem como traços marcantes o abatimento, o temor, a tristeza, as idéias delirantes tristes, o estupor, as alucinações, as idéias suicidas. As doentes julgam-se arruinadas, perdidas e desonradas. A mania puerperal, a forma mais comum, caracteriza-se pela insônia, concepções delirantes, desordem das faculdades, violência dos atos, tumulto de idéias e sentimentos. Às vezes, também aparece a erotomania, o recurso, por mulheres recatadas e escrupulosas, a injúrias e palavras grosseiras e obscenas, a aversão pelas pessoas que lhe são caras, a analgesia, a abolição da sensibilidade cutânea, os olhares desvairados e as alucinações. As observações coletadas pelo autor na Casa de Saúde Dr. Eiras indicam que as idéias de infanticídio também são freqüentes. Em um caso, a doente chegou mesmo às vias de fato, atirando o filho recém-nascido ao chão (Franco, 1877:41-45).

A tese de Cincinato A. Lopes (1877) segue a mesma argumentação que a anterior. Apresenta uma característica singular que diz respeito ao sentido mais profundo da loucura puerperal. Para este autor, a maternidade que santifica a mulher também implica sacrifício. É interessante que, se, por um lado, a reprodução é o objetivo central da vida feminina, constituindo uma função inerente à qualidade de ser mulher; por outro, é preciso que ela faça por merecer esta condição. Para a mulher atingir a plena realização, que é ser mãe, ela precisa suportar sofrimentos e passar por provas, mostrando que é digna de uma tarefa tão importante. A última dessas provas se refere a enfrentar as desordens advindas com o estado puerperal. Lopes (1877:3) coloca isto no plano dos desígnios divinos ao 
dizer que: "É a mulher a heroína dileta da Providência para o sacrifício imenso e misterioso que a deve santificar tornando-a mãe!" O autor adiciona que é a própria Divindade quem faz a mulher passar por provas, entre as quais a da puerperalidade, este "último favo tóxico", "último teste do amor materno".

A leitura que faz Pedro de A. Nabuco de Araujo (1883) concorda com a idéia geral de que a mulher a partir da "cópula fecundante" entra em um estado de "morbidez iminente", que se torna ainda mais delicado no puerpério. Para Araujo, esta fase da vida feminina, assim como a menstruação, a gestação, o parto e a lactação, constitui um momento em que a mulher pode se achar inesperadamente privada da posse de suas faculdades e da direção consciente de seu entendimento. Dessa forma, ela pode causar problemas sérios. É em função dessa possibilidade frente à importância da tarefa feminina na sociedade que o autor justifica a realização de uma tese que tem a mulher como objeto privilegiado, dizendo: "A especialíssima tarefa que ela é chamada a executar na grande obra da constituição das sociedades, justifica plenamente a extrema importância que se deve ligar ao seu estudo bastante complexo visto que a ele se prendem muitos (porque não dizer todos?) problemas sociais" (Araujo, 1883:7).

Além desta justificativa, Araujo esclarece, na abertura de seu trabalho, que recorreu a uma revisão teórica e à pesquisa prática. Freqüentou o Hospital Pedro II, naquele momento sob a direção de Souza Lima, recolhendo observações sobre os casos de loucura puerperal. Refere-se a nada menos que 69 observações. Com base nesses dados, o autor constatou que esse tipo de desregramento mental, que atinge a mulher desde o momento do parto até a volta das regras, pode se caracterizar por delírios, manias, convulsões, além de freqüentes maus-tratos aos filhos (como atirá-los ao chão) ou mesmo tentativas de matá-los (jogando-os pela janela ou estrangulando-os, por exemplo). Araujo ainda afirma que variações desse tipo de loucura acontecem durante a gravidez (loucura da prenhez ou gestação) $e$ também desde a quinta ou sexta semana após o parto até o fim do aleitamento (loucura da lactação ou aleitamento). Quanto a este último tipo, o autor coletou informações a respeito de trinta pacientes.

No que diz respeito às causas do problema, refere-se em primeiro lugar à educação, à idade e à herança. Entre as causas predisponentes estão a anemia, a sensibilidade do estado geral advinda com a gravidez, a histeria (em muitas vezes ligada ao onanismo e aos excessos sexuais), o 
estado moral, o número de partos e os acidentes da gestação e do parto. Já as hemorragias, a dor, a supressão dos fluxos menstruais, o uso do clorofórmio, o frio e a mudança de hábitos constituem o que Araujo chama de causas determinantes. Contudo, o autor observa que o fator moral tem grande destaque, o que é comprovado por alguns exemplos. Algumas mulheres cometeram infanticídio em função do desgosto por terem dado à luz uma menina. Um caso singular é relatado sucintamente em uma das "observações clínicas" do médico, referente à paciente X: "Casara-se, estando prenhe de um amante; e o marido suporta este ultraje, até que, ao dar ela à luz o primeiro filho dele, voltando um dia para casa um tanto ébrio, diz à mulher: Ao menos este assemelha-se a mim. Subitamente delírio agudo muito violento; morte no terceiro dia" (Araujo, 1883:65. Grifo do autor). As explicações de ordem moral parecem vir na frente e suplantar quaisquer outras.

Araujo dedica a última parte de sua tese à medicina legal relativa aos casos de loucura puerperal "real ou não". Adverte aos leitores que este é um assunto muito difícil. Mais uma vez entra em cena a grande dúvida sobre a honestidade das mulheres. Toda a delicadeza do problema está em conseguir distinguir os casos em que a mulher agiu erradamente em função de motivos egoístas, diferentes daqueles que envolvam a alienação. E, admitida a alienação, deve-se descobrir se é transitória ou permanente. Araujo defende que a loucura puerperal é sempre do tipo temporária. É em virtude de alterações provocadas pela gravidez e pelo parto que a mulher é impelida a atos desgovernados. E ficando provado que a criminosa sofre de alienação, é preciso irresponsabilizá-la. Ainda é necessário dizer que os crimes cometidos, citados pelo autor, constituem, na maioria dos casos, na morte do filho recém-nascido.

A tese de Oscar S. R. de Oliveira, defendida no ano anterior (1882), mostra como o tema era discutido a partir de diferentes perspectivas. Este autor foi o único encontrado que forneceu indícios que levam a crer que, sob o rótulo da loucura puerperal e dos crimes de infanticídio cometidos, escondem-se motivos de ordem mais racional ou pragmática. O termo utilizado continua sendo loucura, mas Oliveira descreve as causas do desvio de uma outra maneira. Vejamos o trecho a seguir:

A concepção, que para algumas mulheres é o cúmulo da alegria e a realização de seus mais fervorosos votos, é para outras uma fonte de desgostos e contrariedades. 
Uma mulher já carregada de familia e em más circunstâncias pecuniárias, reconhecendo-se grávida, pensando no futuro, é facilmente atacada pela loucura puerperal. Outras vezes uma prostituta, que mercadeja os seus encantos e faz transações com o amor, vendo-se grávida, compreende que sua cotação vai baixar por este fato, e irritase e desespera-se, do que pode resultar a loucura puerperal.

Mais frequentemente o abandono de um sedutor e o temor da vergonha produzem nas moças a explosão da loucura puerperal. (Oliveira, 1882:25)

O que está sendo descrito pelo autor, em alguma medida, se refere a situações objetivas em que a gravidez e o nascimento de uma criança se dariam em condições bastante problemáticas. O fato de Oliveira apresentar estes aspectos indica que havia um certo reconhecimento de uma relação de causalidade entre tais razões e o suposto estado de loucura, que poderia mesmo levar à supressão da criança. Mas o interessante é que os motivos descritos, bem como o estado de desespero ou de pragmatismo dramático em que mergulhavam estas mulheres não são de forma alguma passíveis de explicação racional. Explica-se necessariamente o infanticídio a partir da insanidade, jamais podendo ser cometido por uma mãe em sã consciência. ${ }^{1}$

A tese de Alipio Azevedo, defendida em 1919, ilustra como já no começo do século XX novas variantes tinham sido introduzidas na discussão do tema. O autor se refere às "psicoses puerperais" como sendo causadas por um processo de auto-intoxicação. As alterações da nutrição relacionadas ao acúmulo de toxinas externas ou resultantes da oxidação e eliminação defeituosa, ao lado de distúrbios no sangue e no peso, seriam responsáveis pelas perturbações sofridas pelas mulheres no puerpério. Além disso, a mulher teria passado muitos meses sem os benefícios da eliminação de substâncias tóxicas que acontecia com a menstruação. A hereditariedade, o esgotamento nervoso, as infecções e as emoções fortes continuam sendo fatores considerados importantes para a explosão da loucura puerperal.

O trabalho de Azevedo (1919) também tem o mérito de nos mostrar como a essa altura a loucura puerperal era um terreno disputado pela obstetrícia e pela psiquiatria. O autor chega mesmo a admitir que a doença deve ser tratada pela conjunção das duas especialidades, mas defende que o seu trabalho é efetivamente de obstetrícia. Segundo ele, ao obstetra cabe evitar os surtos de alteração mental que acometem a gestante. Da mesma forma, quando a psicose já estiver em curso, é este médico que deve ser o 
responsável por estudá-la e tratá-la. E acrescenta que as doentes de psicose puerperal não devem ser misturadas com outros tipos de loucos, por isso não devem ser levadas aos hospícios. Devem ser mantidas nas maternidades ou mesmo em casa, recebendo todos os cuidados fornecidos pelo obstetra. ${ }^{2}$

Se compararmos as teses sobre loucura puerperal e aquelas sobre infanticídio, veremos que têm muitas semelhanças. Isso leva a pensar que o infanticídio talvez seja o principal sintoma, ou, pelo menos, o mais grave resultado das perturbações mentais advindas com o puerpério. Indo um pouco mais longe, talvez o infanticídio consista na motivação maior para que os médicos tenham que definir a categoria loucura puerperal. O crime da mãe que mata o próprio filho é de tal forma contrário ao ideal da maternidade, supervalorizado no transcorrer do século XIX, que é preciso entendêlo de outra forma.

A solução proposta pelos médicos - e que teve conseqüências que vão muito além do campo da medicina - envolve a associação entre infanticídio e loucura puerperal. É certo que nem todos os infanticídios cometidos foram lidos pela ótica da loucura puerperal e também que as manifestações decorrentes deste tipo de perturbação mental não se resumem àquele. Mas, se observarmos a lógica interna das teses, o enredo da argumentação e as mudanças ocorridas no decorrer do tempo, bem como a comparação com outros temas que ganham ou perdem destaque, veremos que esta associação é bastante resistente e significativa.

É interessante, por exemplo, que nas primeiras décadas do século XX não tenhamos registro de nenhuma tese sobre infanticídio, um tema que tinha atraído o interesse dos médicos durante toda a segunda metade do século anterior. ${ }^{3}$ Já a loucura puerperal é tratada em teses que vão desde 1877 até pelo menos $1927 .{ }^{4} \mathrm{E}$ quanto ao chamado aborto criminoso, as referências vão de 1873 a $1925 .{ }^{5}$ Com base nisso, sugiro que cada vez mais o infanticídio, que não deixa de ser cometido pelas mães e nem de ser tratado pelos médicos, passa a ser encapsulado pela noção de loucura puerperal. Ou seja, a partir de um determinado momento, não há mais teses sobre infanticídio porque os casos desse crime e a preocupação dos médicos a respeito dele são considerados dentro da ótica da loucura puerperal.

Um outro dado, que fornece uma explicação que se pode combinar à anterior, diz respeito à relação entre infanticídio e aborto. Com a propagação 
de informações e das técnicas abortivas a partir do final do século XIX, é provável que o aborto tenha suplantado o infanticídio como um meio de controle da natalidade empregado já após a gravidez consumada. A predominância das teses sobre aborto também a partir dessa época refletiria uma mudança na prática, sinalizando um redirecionamento da atenção dos médicos para a questão do aborto.

\section{O Infanticídio}

A tese de Antonio José Pereira Neves já no ano de 1839 discutia o infanticídio, ou seja, a morte violenta ou premeditada de uma criança recém-nascida ou na ocasião do nascimento. A polêmica em torno do conceito de recém-nascido era grande e persistiu durante boa parte do século XIX. Mas a maioria dos autores concordava em admitir que a queda do cordão umbilical deveria indicar o limite da noção de recém-nascido. Essa e outras questões deveriam preocupar o médico legista. Neves explica que essas questões são de duas ordens. A primeira se refere ao estado da criança. Além de saber se a criança envolvida é um recém-nascido, é preciso descobrir se viveu depois do nascimento, por quanto tempo e desde quando está morta. Além disso, é necessário determinar se a morte foi natural (ou seja, por omissão de cuidados) ou violenta (por comissão, asfixia por estrangulamento, sufocação ou submersão, fratura, luxações, feridas, combustão ou envenenamento). A segunda ordem de questões é relativa ao estado físico e moral da mulher. No primeiro caso, o legista solicitado deve considerar se a mulher pariu recentemente, se há coincidência entre a época do parto e o nascimento presumido da criança e se a criança 'pertence' à mulher acusada.

Antes de entrar na discussão sobre o estado moral da mulher, Neves faz uma advertência importante. Afirma que o crime do infanticídio

é mais vezes cometido por mulheres, não de condição baixa, mas por aquelas de uma honra e reputação imaculadas. Estas, possuídas de sentimentos nobres, excogitam imensos meios para encobrir sua prenhez e dar à luz debaixo de todo o segredo; então, não é raro que se exponham involuntariamente ao risco de extinguir a vida a seu filho. Sim, o susto, o receio de perder sua honra e de patentear sua fraqueza excitarão sua alma e produzirão em seu organismo um estado como de alienação. De certo um tal estado deve antes suscitar-nos compaixão do que ódio e vingança. (Neves, 1839:48) 
O trecho citado indica, em primeiro lugar, que o infanticídio era praticado por mulheres de boa reputação e condição social elevada. E que estas mulheres eram levadas a tal atitude em função de sentimentos nobres associados à manutenção da honra. A preocupação com a honra era tanta que se "expunham involuntariamente ao risco" do infanticídio. Notase que o autor tem todos os cuidados em não chamar essas mulheres de criminosas, de exaltar a valorização da honra e solicitar compaixão. O que parece estranho, à primeira vista, é que há um certo deslizamento muito rápido entre reconhecer o infanticídio para salvaguardar a honra, uma estratégia consciente, e supor um estado de alienação. Na verdade, a prevalência da honra nesse momento reflete não só a preocupação dos médicos, mas está inscrita no próprio Código Criminal de 1830. O artigo 197 punia quem matasse um recém-nascido com a pena de prisão de três a doze anos. Já o artigo 198 ponderava que se a própria mãe fosse a autora do crime e tivesse assim procedido para ocultar a sua desonra, a pena diminuiria para um a três anos de prisão, uma redução bastante considerável.

Voltando às questões que devem orientar o legista, Neves relaciona, quanto ao estado moral da mulher, três perguntas. A primeira é se a mulher pode ignorar a sua prenhez. $O$ autor previne que as mulheres costumam alegar esta ignorância. Mas, na sua opinião, as chances de desconhecimento são bem exíguas. A mulher teria de ser idiota ou ter sido fecundada quando adormecida por substâncias narcóticas, embriagada, atacada de asfixia ou histeria. A segunda pergunta é se a mulher pode parir sem saber. $O$ autor responde afirmativamente apenas para o caso em que estivesse sob a influência de substâncias narcóticas ou o parto se desse na hora da defecação e a mulher confundisse as dores do parto com as da evacuação. Neves afirma que freqüentemente se alega isto, mas que os casos reais são bastante raros. A última questão concerne ao fato de se a mulher logo depois do parto está em condições de dar ao recém-nascido todos os cuidados. O autor responde que o parto é algumas vezes tão tumultuado e perigoso que perturba todo o organismo feminino, transformando as faculdades do corpo e da alma. A mulher pode então sofrer forte hemorragia, cair desfalecida, ter convulsões, ataques de apoplexia e histeria, adormecendo ou mesmo sofrendo morte aparente. Nestas situações, não tem condições de prestar assistência à criança recém-nascida.

Todos esses fatores devem levar o médico a ser bastante prudente para não acusar inocentes injustamente, mas, em contrapartida, para 
punir aquelas que, em sã consciência, cometeram um crime que as torna mais cruéis que as feras:

Se mulheres, já bem punidas pela perda involuntária e acidental de seus filhos, merecem, quando iniquamente acusadas do crime de infanticídio, comiseração e brandura; ao contrário, a natureza, a humanidade e a justiça recusam toda espécie de indulgência àquelas que, mais cruéis do que as próprias feras, arrancam aleivosamente a vida a seus fracos e inocentes filhos! (Neves, 1839:51-52)

A tese de Neves, talvez pelo seu caráter pioneiro, vai inspirar uma série de outras. É o caso, por exemplo, do trabalho de Luciano A. de Oliveira (1852). O conceito de infanticídio e outros pontos da argumentação se assemelham ao que foi visto anteriormente. As questões relativas à criança e à mulher também se repetem. Neste caso, podemos presumir que os médicos legistas continuavam seguindo as mesmas orientações das décadas anteriores.

Contudo, no mesmo ano temos uma tese que se distingue bastante das anteriores, ao aprofundar alguns quesitos relativos ao infanticídio. Joaquim A. Pinheiro de Castro (1852) apresenta algumas explicações importantes no que se refere à diferença entre infanticídio, feticídio e embriotomia, termos comuns na época. O autor esclarece:

Parece que, em linguagem rigorosa e castigada, se deveria empregar a palavra feticídio, quando se tratasse de significar genericamente o aniquilamento do feto desde a época de sua formação até a de sua expulsão; de embriotomia para exprimir tão somente a idéia de fazer morrer o feto no seio materno, ainda antes de sua formação, e de infanticídio quando se tratasse do morticínio de um feto viável. (Castro, 1852:5. Grifos do autor)

Castro não entra em detalhes, mas, se observarmos o conjunto das teses e outros trabalhos da época, veremos que o termo embriotomia quase sempre é empregado quando se trata de uma operação realizada por médicos, em função de várias razões que, definidas genericamente, colocariam a vida da mãe em risco. O feticídio, às vezes, apresenta a mesma conotação quando é acrescido do adjetivo terapêutico. O mesmo se dá com o termo aborto obstétrico. O que parece importante nestas definições é que os médicos estão tentando distinguir a sua prática das intervenções realizadas pelas próprias mulheres ou por 'comadres', 'parteiras', pessoas não habilitadas e inescrupulosas. Neste caso, o que estaria em foco seriam as 
tentativas de restrição da natalidade. Embora os médicos tentem justificar os métodos adotados por eles mesmos, a variação dos motivos para se fazer uma embriotomia, feticídio terapêutico, aborto obstétrico pode ser tão grande, e às vezes quase indistinguível da prática dos 'outros', que o critério de diferenciação mais ressaltado parece recair sobre a autoria do ato praticado. Ou seja, um feticídio cometido pelo médico, pelo menos a priori, é justificado, enquanto o cometido pela própria mãe ou por terceiros é delituoso.

Contudo, em se tratando do infanticídio, a situação é outra. Trata-se de um crime cometido pela mãe. $O$ interessante é que mesmo diante dessa diferença tão acentuada, Castro, assim como outros autores, invoca para todas as práticas a mesma explicação. Isso revela que embriotomia, aborto, feticídio e infanticídio talvez fossem vistos muito mais na ótica de um contínuo do que a partir de uma distinção absoluta. Eram fatos da mesma ordem. Implicavam a coibição do aparecimento de uma nova criança, processo que poderia ocorrer em diferentes momentos, desde o começo da gravidez até os primeiros dias após o nascimento. A identificação do momento em que uma vida independente estava formada ou mesmo uma nova alma se constituía era governada pelas especificidades da época. Porém, para os médicos, especialmente aqueles que lidavam com o delicado terreno da reprodução, era preciso elaborar uma ruptura clara com aquilo que estaria no domínio explícito do controle da natalidade, julgado como moralmente condenável. O curioso é que o discurso sobre esta ruptura não incide tanto sobre as razões médicas que levariam à prática de um aborto e nem sobre o tipo de técnica empregada, que poderia aproximar ainda mais os médicos dos 'outros', mas sobre a qualificação do praticante. Defende-se que somente os médicos teriam a autoridade para decidir acerca de um caso de aborto e, em qualquer outra situação, o recurso a este ato deveria ser prontamente condenado. Pode-se lembrar ainda que na disputa com as parteiras, a discussão sobre a prática do aborto foi bastante importante. E embora os médicos alegassem superioridade moral diante das parteiras, que segundo eles fariam abortos sempre que solicitadas, talvez estivessem também interessados em monopolizar essa prática, traduzindo-a nos termos das justificativas médicas.

A tese de Castro (1852:5) ainda nos esclarece que, para discutir o problema, faz-se necessário inserir a medicina em debates mais amplos. Segundo o autor: "No vasto domínio da medicina aplicada à economia 
política há poucos objetos que tenham tanto fixado a atenção dos médicos e exercitado sua pena, como o infanticídio." O infanticídio é um problema que diz respeito ao desenvolvimento da população. Este crime estaria coibindo o crescimento do número de cidadãos e, portanto, impedindo o progresso econômico e ameaçando a soberania da nação. Além disso, o infanticídio acaba com uma vida que já pertencia à sociedade e que dela foi usurpada. É a partir desta discussão que Castro (1852:6) explica as diferenças entre o aborto e o infanticídio:

aos olhos da sociedade se encara como mais execrável o infanticídio que o aborto; a ordem social se ressente do primeiro, porque ele aniquila um ser, que virtualmente já lhe pertence; ressalta mais que a perpetração deste atentado revela a maior atrocidade que o crime de aborto pelo princípio de que - aquilo que os olhos não vêem, o coração não sente e é que na natureza humana nossas afeç̧ões nascem e crescem à medida que a sensibilidade dos sentidos externos reflete os objetos no sensorium, tocando-os; ainda porque o amor materno partilha até das feras (...).

O aborto seria menos nocivo à sociedade. Afinal de contas, ainda não se trataria de um ser completamente formado, sendo menor o prejuízo, e menos desumano o ato, já que a mulher não vê a criança. Note-se também que o contato físico e visual entre mãe e filho após o nascimento seria o responsável pelo desenvolvimento do tão falado amor materno. Castro acrescenta que é em virtude destes motivos que a sociedade prevê punições bastante distintas para os dois crimes. Na França, por exemplo, enquanto o autor do aborto era punido com a reclusão, o infanticídio era castigado com a morte. ${ }^{6}$

$\mathrm{O}$ aborto e o infanticídio constituem temas que evidenciam como certos tipos de perturbações ligadas ao corpo feminino são percebidas como perigosas inclusive para a sociedade. Como conseqüência, os médicos que estudam e tratam das mulheres se lançam também à análise e à elaboração de prescrições relativas às possíveis desordens (e mesmo crimes) causadas por estas mulheres. Fazem isso utilizando-se do conhecimento de outras disciplinas (como o direito, por exemplo), o que implica convergências, mas principalmente disputas com colegas de áreas distintas.

\section{O Aborto}

A questão do aborto aparece nas teses da Faculdade de Medicina do Rio de Janeiro entre 1840 e 1931 em 66 trabalhos. A maioria dos títulos 
se divide entre o estudo do aborto, suas causas, seu tratamento, os casos em que deve ser provocado (especialmente em função dos vômitos incoercíveis), os conceitos de feticídio terapêutico, aborto obstétrico ou terapêutico e aborto criminoso. ${ }^{7}$ Quanto ao chamado aborto criminoso, registram-se nove casos, concentrados entre 1873 e 1925.

Em boa parte das teses, como a de Pedro F. da Silva Pires (1892), há uma preocupação em elaborar tipologias do aborto. Ele pode ser espontâneo, acidental ou provocado. De acordo com as fases, é classificado como ovular (até trinta dias após o início da gestação), embrionário (entre trinta e noventa dias) e fetal (do fim do terceiro mês ao fim do sexto mês). ${ }^{8}$ Além disso, apresentam-se seus sintomas e marcha, o diagnóstico, o prognóstico e o tratamento. Os fatores predisponentes também são considerados com cuidado. Entre eles, destacam-se a idade e o temperamento da mãe, a herança biológica, os hábitos, a alimentação, o meio em que vive, as doenças, a conformação da bacia etc. Pires alerta que, na época em que escrevia, já estava provado que as características do pai também poderiam agir na interrupção espontânea da gravidez. Afirma que, por muito tempo, negou-se que o pai pudesse ter influência prejudicial sobre a gestação, mas que, com os estudos de mulheres estéreis com um primeiro marido e férteis com um segundo, esta hipótese tinha sido definitivamente abandonada.

Uma leitura do conjunto das teses revela que a questão do aborto era delicada e tratada pelos médicos sob vários ângulos. A decisão sobre a realização do aborto terapêutico, por exemplo, para uns parecia não provocar maiores problemas, enquanto para outros a consulta a colegas e a consideração da posição da Igreja criavam, muitas vezes, situações sem solução. Um exemplo interessante é relatado no Brazil Medico de 1895. O dr. Benjamin Moss, de Ouro Preto, escreve sobre um caso de nevrose complexa, histero-epilepsia, vômitos incoercíveis, resolvido com a provocação do parto prematuro. Segundo o médico, tratava-se de uma senhora de 25 anos, casada, multípara, clorótica, de constituição débil, afetada por nevralgias e acessos histéricos mais ou menos prolongados. Histérica desde a puberdade, descendia de pais já velhos, consangüíneos. A mãe era excessivamente nervosa e facilmente impressionável e o irmão tinha acessos constantes de loucura e vivia preso. Além do mais, de acordo com Moss, a paciente tinha sido educada em um centro religioso e sua mãe ultrapassava os limites do exagero com sua monomania religiosa. Este fato comprovaria a teoria de Charcot e Gilles de la Tourette sobre a influência da 
prática religiosa na histeria. Com o exame, o médico diagnosticou que se tratava de um caso de nevrose complexa caracterizada pelo excessivo grau de impressionabilidade do sistema nervoso (Moss, 1895).

A moça estava grávida de três meses e temia a ocasião do parto. O anterior, quando nasceram gêmeos, tinha sido muito trabalhoso. Sofria de nevralgias que tinham sido tratadas sem sucesso por vários outros médicos com o emprego de eletricidade, hipnotismo e cauterizações do colo do útero. Chamado às pressas no meio da noite, o dr. Moss primeiro aplicou injeções de morfina e inalações de clorofórmio para o repouso da enferma. No dia seguinte, examinou o útero da paciente e encontrou-o "e forma bem pouco lisonjeira", especialmente em função das cauterizações. Procedeu o tratamento com lavagens e óleo de amêndoas e um "arsenal terapêutico monumental" de fórmulas que continham bromuretos de potássio, sódio, amônio, cânfora, litina, sulfonal, castóreo, almíscar, valeriana, valerianato de zinco, assa-fétida, zumbul, melissa, beladona, sulfato e cloridrato de morfina, ópio, valerianato de quinino, clorofórmio, éter, picrotoxina, fosforeto de zinco, actea ramosa, cloral, cocaína, citulina, hiosciamina, atropina, paraldeide etc.

Apesar da variedade dos compostos empregados, a paciente não apresentava melhoras. As nevralgias pioraram, resultando em acessos histérico-epilépticos caracterizados por gritos repetidos, prolongados e atordoados durante o período clônico, rigidez geral, atitude variável dos membros, movimentos clônicos muito extensos e muito variáveis, projeção do tórax, da bacia, timpanismo etc. Sofria também de espasmo da glote e esofagismo, não se alimentava e os vômitos tornavam-se incoercíveis. Depois de três ou quatro meses o quadro havia piorado ainda mais e uma intervenção mais enérgica se fazia necessária. O dr. Moss convoca então dois outros colegas e sugere que a única possibilidade de salvação da mãe era a provocação do parto prematuro. Os dois clínicos chamados discordaram, segundo Moss, devido a escrúpulos excessivos. Como o estado da doente era gravíssimo, o médico convida por carta oito colegas a opinarem sobre o assunto. Quatro responderam, discordando da realização do aborto. Apenas o dr. Sizinio Pontes, lente da escola de farmácia, foi favorável e dividiu com Moss a responsabilidade. Foi solicitada também a avaliação do dr. Henrique Diniz, secretário do interior do governo de Minas Gerais, que também concordou com a proposição. O parto prematuro, na verdade a aplicação de uma esponja preparada com abortivos, foi então realizado. Os acidentes nervosos desapareceram e semanas depois a doente teve alta. 
A decisão de realizar do aborto terapêutico parece dividir os médicos entre aqueles que assumiam a sua necessidade e aqueles que preferiam, pelo menos publicamente, se abster de tal compromisso. Quanto à prática, alguns trabalhos relatam os meios empregados de uma forma que deixa transparecer que o procedimento não era incomum entre os médicos e se conheciam muito bem os instrumentos adequados. Há mesmo alguns textos que demonstram a validade de cada meio. Um dos mais claros é assinado pelo dr. Abel Parente no próprio Brazil Medico de 1895. Nesse artigo a respeito da importância do nitrato de prata - Abel Parente apresenta os meios para provocar o aborto obstétrico. Os principais eram:

1. Perfuração das membranas: a) no orifício (método inglês); b) superiormente ao orifício (método de Meisser e Villeneuve).

2. Sem perfuração das membranas: a) praticando injeções uterinas (método de Cohen); b) introduzindo e retirando um catéter (método de Lehmann); c) deixando de permanência um catéter (método de Krause).

3. Descolamento das membranas do segmento inferior do útero: a) com o auxílio dos dedos (método de Hamilton); b) com o auxílio do catéter (método de Riché); c) com a ducha uterina aplicada no segmento inferior (método de Kiwisch); d) introduzindo o tubo no colo (método de Blot); e) empregando água quente (método de Kiwisch e Schroeder).

4. Dilatação do orifício uterino: a) com a esponja preparada (método de Kluge); b) com a laminária (método de Simpson e Sims); c) com instrumentos (método de Basch, Krause e Rizzoli); d) com sacos elásticos (método de Tarnier e Barnes).

5. Tamponamento vaginal: a) com fios ou algodão (método de Scholler); b) com uma bexiga animal (método de Huter); c) com o colpeurinter (método de Braun).

6. Com o centeio espigado (método de Bongioranni e Ramsbothom).

7. Com a pilocarpina (método de Kleinwachter, Sanger, Bidder, Weiss etc.).

8. Irritação do bico do seio (método de di Scanzoni).

9. Cauterização da superfície interna do colo uterino pelo nitrato de prata (método de Giordano).

10. Eletricidade: a) corrente galvânica (método de Redfort e Schreider); b) corrente induzida (método de Henonig e Lilschukuss). (Parente, 1895:230) 
No que se refere à decisão da prática do aborto obstétrico, o trabalho mais interessante parece ser o livro Lições de Clínica Obstétrica, de Fernando Magalhães (1917), que resume suas aulas ministradas na Faculdade de Medicina. Em um capítulo sobre o feticídio terapêutico, o autor começa descrevendo como a proibição religiosa prejudica a ação profissional. Fala de como tem variado a doutrina da Igreja no que se refere ao momento em que o embrião passa a ser dotado de alma até chegar à concepção, em curso que proclama a inviolabilidade da vida embrionária desde a fecundação. ${ }^{9}$ Magalhães (1917:360) é contra a opinião eclesiástica rigorosa que não admite nenhuma exceção: "Não é possível reconhecer na autoridade canônica competência em matéria de obstetrícia; com o simples enunciado do decálogo - não matarás - resolvem os sectários a conduta do prático em qualquer emergência clínica. A doutrina é errônea e desumana." O médico que seguir estas regras intolerantes acabará assistindo à morte da gestante e também do embrião. Já o médico que age cientificamente interrompendo a gravidez é mais humanitário, pois poderá salvar a vida da mãe. As autoridades da Igreja agem sem conhecimento das questões obstétricas. O médico, que sabe das condições em que uma gravidez deve ser interrompida devido ao seu domínio da ciência, não precisa consultar ou pedir conselhos aos religiosos. Magalhães insiste diversas vezes que a questão é científica, e não de natureza religiosa. ${ }^{10}$

Cabe ao médico ter clareza quanto aos estados em que o aborto é indicado. Alguns desses estados dizem respeito ao sistema nervoso, como a polinevrite grave (perturbações de sensibilidade seguidas de desordens motoras) e a coréia gravídica. Outras indicações se referem a casos de tuberculose, lesões ou moléstias graves do aparelho respiratório, nefrites, cardiopatias, anemia perniciosa progressiva, moléstias do aparelho circulatório e urinário, toxemia gravídica e acidentes ligados ao ovo, como as hemorragias. Em se tratando de tuberculose e cardiopatia, Magalhães sugere mesmo que a profilaxia deva vir com a interdição do casamento. Nos casos de cardiopatia chega a falar em esterilização da paciente. E na discussão sobre a importância do pulso acelerado como indicação para a interrupção da gravidez (proposta por Pinard), mostra como havia discordâncias e dúvidas entre os autores. O que era indicação segura para uns, não merecia a atenção de outros, levando a crer que ainda não havia uma doutrina única e segura (também em termos morais) para os médicos. Magalhães conclui que a decisão clínica deve ser orientada pela 
persistência de todos os sintomas, apesar do tratamento ministrado pelo médico. Este quadro de piora da paciente, que não responde ao tratamento, é que deve configurar a indicação para o aborto. Desde que diagnosticado o quadro, é preciso correr para salvar a vida da mãe. A vida do feto também é importante - e Magalhães diz que é a ciência, e não a religião, que comprova isto -, mas é uma vida que não é própria, mas dependente da mãe, subsiste apenas enquanto a vida materna subsistir. Cabe, assim, em primeiro lugar, tentar proteger esta última. ${ }^{11} \mathrm{O}$ autor ainda disserta sobre a natureza da vida fetal, considerando os métodos de interrupção da gravidez e condenando a chamada embriotomia no feto vivo.

O que se pode depreender dos trabalhos de Magalhães e de outros autores é que a medicina tentava legitimar sua doutrina e prática frente a concepções mais tradicionais, especialmente àquelas que se originavam no pensamento religioso. A grande arma utilizada pelos médicos era a objetividade do conhecimento científico que garantiria a correção de suas atitudes e justificaria sua autoridade. Esta mesma autoridade que previa a possibilidade do aborto terapêutico era invocada para condenar o chamado aborto criminoso.

\section{O Crime dos 'Fazedores de Anjos'}

Especialmente a partir da década de 1910, o aborto criminoso passou a chamar a atenção dos médicos e a aparecer como um tema de destaque tanto nas teses quanto nos periódicos e outras publicações. Em 1911, Antonio F. da Costa Junior apresentava à Faculdade de Medicina um dos mais completos trabalhos sobre o tema. Na elaboração de sua tese, o autor recorreu não só à pesquisa bibliográfica, mas a entrevistas com médicos famosos e à compilação de processos judiciais, compondo um documento histórico valioso. Nas primeiras páginas, deixa claro que está preocupado em mapear a freqüência deste crime no Rio de Janeiro e em propor meios para sua repressão, já que a extinção total seria uma utopia. Justifica a escolha do tema de tese da seguinte forma:

As proporções a que, em nossos tempos, tem atingido este crime, tão clara e perfeitamente previsto no nosso Código Penal, nos incita, ainda mais revoltados pela sua vergonhosa impunidade, a pôr em evidência a sua brutalidade e hediondez, e a procurar um meio de saná-lo, quer com medidas de ordem moral, quer com medidas de ordem legislativa. (Costa Junior, 1911:22) 


\section{E acrescenta que é preciso:}

dar sempre combate a esta desmoralizadora prática, que tem apóstolos quer entre simples curiosos, quer entre profissionais de ambos os sexos, a qual, avassalando desoladoramente os nossos costumes, tem concorrido poderosamente para calcar ainda mais, o nosso nível moral já tão deprimido. (p. 23)

$\mathrm{Na}$ introdução da tese, Costa Junior explica que o aborto é um crime existente tanto em povos civilizados quanto incultos. Os motivos variam de um país para outro. Em alguns, serve para evitar o excesso de população, em outros para eliminar indivíduos fracos. Mas, a principal causa, desde as épocas mais remotas, tem sido a depravação do meio social. Exemplificando, o autor nos esclarece os diversos motivos que levavam mulheres de distintas posições a tal prática, todos encapsulados sob o rótulo da depravação:

Assim, é a mulher casada que engravida na ausência do marido, é a mulher freqüentadora do meio chique, e cuja gravidez lhe impediria de continuar a comparecer às festas, reuniōes etc., é a demi-mondaine, perturbada no exercício de sua profissão por uma gestação importuna, é a amásia que se vê surpreendida por uma gravidez inesperada, e finalmente a representante da classe burguesa, cujo modesto orçamento seria desequilibrado pela vinda de uma criança, que têm achado, como único curso para a sua situação, a prática do aborto. (Costa Junior, 1911:25-26)

Costa Junior passa então em revista a prática do aborto nos mais diferentes países e épocas, desde a Grécia antiga, passando pelos 'povos selvagens', até os países da Europa. Afirma que na Inglaterra esta prática é punida rigorosamente; na Itália, é praticada em casas especializadas; na Suécia, é abundante; nos Estados Unidos, há uma completa tolerância, sendo o aborto praticado em larga escala, e seu número é calculado em 80 mil por ano. Já na França, o crime do aborto é muito perseguido e punido, o que não impede que o número cresça ano a ano. E na medida em que o número de abortos cresce, o número de condenações tem diminuído, demonstrando a impotência da justiça diante da habilidade e discrição dos praticantes. Naquele país, o aumento do número de abortos concomitante ao decréscimo do número de partos tem alarmado os poderes públicos. As estatísticas provam que a população tem diminuído assustadoramente. A média de nascimentos por casal é de apenas 2,7 na 
França, enquanto na Alemanha chega a 4,4 e na Inglaterra é de 3,7. Quanto ao Brasil, o autor declara que, entre outras importações estrangeiras, também recebemos a da prática do aborto criminoso, que aqui progrediu bastante, apesar das disposições legais em contrário.

Costa Junior (1911:32) ainda acrescenta que na Alemanha discutese a absurda e condenável idéia do direito ao aborto:

Os defensores desta repulsiva teoria, que tem a frente Listz, acham que a mulher é dona do próprio corpo, e que, por isso, pode dispor dele à sua vontade, sacrificando, se assim o quiser, o fruto de sua concepção, considerado por eles como uma parte do corpo, que tem tanto valor como um dedo, um membro etc.

Os partidários desta teoria têm requerido a supressão do artigo do Código Penal alemão que trata do aborto. Mas, segundo Costa Junior, não conseguirão o que desejam porque a sociedade não iria sancionar tão degradante costume, já que reconhecer o direito ao aborto seria dar um golpe na própria base da sociedade, desorganizar a família, justificar todos os atentados contra a pessoa, legitimar o homicídio.

Ainda segundo o autor, o feto é um ser que tem direito à vida $\mathrm{e}$ adquire personalidade a partir de um mês e meio após o início da gestação. E considerando que o feto é uma pessoa, ninguém teria o direito de dispor dessa vida sem cometer um crime. Além disso, Costa Junior (1911:33-34) ressalta que o produto da concepção pertence também ao Estado:

O produto da concepção normal não pertence só à mãe, ele pertence também ao Estado, do qual virá fazer parte e como tal, este deve zelar pela sua vida.

A prática do aborto criminoso é um crime por excelência anti-social, pois que suprime o indivíduo, membro da família, de que se compõe o Estado.

O passo seguinte da tese é demonstrar a existência do aborto criminoso no Rio de Janeiro. Costa Junior começa afirmando que a principal culpada é a própria mulher grávida - tese que seria relativizada no decorrer do trabalho. É ela que, sob os mais variados pretextos, decide pôr fim à gravidez, muitas vezes provocando com habilidade o aborto em si própria. No consultório de obstetrícia da Maternidade de Laranjeiras, o autor examinou uma consultante, casada, com 34 anos e dois filhos, que admitira ter ficado grávida mais de 14 vezes, tendo abortado em todas elas empregando 
hastes de laminária. Contudo, na maioria dos casos, os abortos eram realizados com o auxílio de outras pessoas, profissionais ou curiosas. $O$ cuidado em ocultar a prática, bem como os modernos processos empregados que não deixam vestígios são responsáveis pela pouca publicidade dos casos. É por isso que, apesar da reconhecida freqüência, a polícia não tem registros deste crime. Segundo o autor, somente no ano de 1911 a polícia teria apurado, com a devida perícia médico-legal, o primeiro caso de aborto criminoso.

Costa Junior transcreve toda a documentação referente a este e a outros casos aos quais teve acesso. O material é importante porque, em primeiro lugar, traz informações valiosas a respeito da prática do aborto na época e do que chegava a ser documentado. Em segundo lugar, coloca em evidência o interesse médico no assunto, considerando todo o andamento dos fatos, desde a suposta motivação invocada para o aborto até a trajetória do inquérito e exame médico-legal.

A primeira descrição feita pelo autor começa com o laudo realizado pelos drs. Jacyntho de Barros e Miguel Salles, a pedido de Afranio Peixoto, então diretor do Serviço Médico Legal, referente ao aborto praticado em P. D. A. C. por A. P., parteira não diplomada. No documento, os médicos relatam que P. D. A. C. era uma mulher branca, de 28 anos, casada, moradora de Minas Gerais. Em entrevista no dia 14 de agosto de 1911, esta senhora declarou que era portadora de um vicioso defeito orgânico que a impedia de dar à luz e colocava sua vida em risco. Achando-se grávida, resolveu junto com o marido vir ao Rio de Janeiro para tratar-se com a dita parteira que se anunciava possuidora de segredos para impedir a concepção e praticava abortos. Chegou ao Rio no dia 7 de agosto, e no dia seguinte foi examinada pela parteira com um espéculo, tendo logo depois recebido injeções uterinas por meio de uma sonda. Permaneceu alojada na casa da parteira recebendo as injeções, seguidas de muitas dores, que continuaram até o dia 10, quando ocorreu o aborto. A mulher, que já estava debilitada, começou a passar muito mal e pediu para chamar um médico. O marido transferiu-a para a casa de um parente que também era médico.

O exame efetuado pelos médicos revelou que ela tinha um bom desenvolvimento físico, era bem nutrida e levara a termo quatro gestações. Dois dos seus filhos eram doentes: um imbecil, e outro, atrasado. É realizada uma avaliação pormenorizada das condições de saúde em que se achava P. D. A. C., especialmente com relação aos órgãos genitais. Um exame de sangue e outro de urina também foram requeridos, visando a 
descobrir se haveria indícios da presença de mercúrio, possivelmente aplicado nas injeções. Os resultados foram negativos. Os médicos também fizeram uma avaliação dos objetos encontrados pela polícia na casa da parteira e remetidos ao Serviço Médico Legal. Entre estes objetos estavam:

dois grandes vidros de boca larga, contendo álcool; dois outros pequenos, com um líquido de cor escura; um frasco de 60 gramas com líquido espesso de cor vermelha e o rótulo - uso externo; um vidro com centeio espigado; um outro com medicamento, fórmula preparada na Pharmacia Silva Araujo; um embrulho contendo cascas de madeira; três caixas com vaselina; três caixas de papelão com medicamentos, cinco caixinhas de metal com medicamentos; uma caixa de papelão com empolas de óleo canforado, incompleta; uma caixa rotulada: Comprimidos Guillaumin; um frasco com os mesmos comprimidos, dois vidros de pílulas do dr. Ross; cinco pequenos tubos com pastilhas brancas; dez caixinhas de madeira, vazias, para comprimidos Guillaumin; um vidro com mercúrio vivo; um pequeno frasco de pílulas de Apiolina Chapoteaut; três vidrinhos com medicamentos homeopáticos; um vidro pequeno de bocal amplo, contendo dois embriões, um medindo 12 milímetros e pesando meia (1/2) grama, e o outro de sete centímetros de comprimento, aproximadamente, e sete gramas de peso; três caixas contendo as chamadas 'Camisas protetoras (condoms)'; as caixas são de dúzia, achando-se uma incompleta; dois pessários oclusicos para o colo do útero; dois tubos contendo duas hastes de laminárias, preparados de Hartmann; uma seringa pêra de borracha, sujo internamente o pipo respectivo de uma substância escura; duas sondas de BozemanFritsch, uma incompleta; uma seringa com tubo de injeção intra-uterina, perfurado lateralmente, modelo semelhante ao de Brown; cinco sondas uretrais de goma, de diversos calibres, das quais três tintas da mesma substância, que mancha o pipo da pêra de borracha; uma torneira para irrigador; um espéculo bivalve novo, ligeira modificação do de Cusco, comum; um pincel para garganta; uma pinça para curativos uterinos; uma seringa de Lüer, para dois centímetros cúbicos com caixa metálica nova e mandarins; dois tubos com pequena esponja presa à extremidade por meio de um fio de arame; uma bola-esponja contida em uma rede e suspensa a um fio longo; dois pipos, um de vidro, um de goma, para lavagens vaginais; um condutor de sonda intra-uterina de Collin. (Costa Junior, 1911:47-49)

Essa descrição parece extensa demais, mas, na verdade, é a composição desse arsenal de posse da parteira que vai fundamentar a conclusão dos peritos. O laudo é finalizado com a resposta aos seguintes quesitos, encaminhados pelo delegado: 
$1^{\text {2) }}$ Se do exame da paciente, podem os peritos concluir que tenha havido aborto;

$\left.2^{2}\right) \mathrm{Se}$, no caso afirmativo, o aborto foi espontâneo ou provocado;

3) Se, na segunda hipótese do quesito precedente, podem os peritos determinar qual o meio abortivo de que se serviu a parteira;

4²) Se houve a administração de qualquer substância tóxica e qual ela seja;

$\left.5^{2}\right)$ Se, no caso afirmativo da intoxicação, resultou prejuízo de qualquer espécie para a saúde da paciente;

69) Se entre os diversos objetos apreendidos em casa da parteira, algum existe capaz de servir à prática do aborto, e, se algum há que indique a prática anterior desse crime. (p. 38)

Os peritos respondem 'sim' ao primeiro quesito. Quanto ao segundo, disseram não poder afirmar positivamente, a partir do exame da paciente, se o aborto foi provocado. Mas, considerando o passado e o estado atual da paciente, que não revelam tendência ao aborto espontâneo, bem como suas declarações, respondem que o aborto foi provocado. Em seguida, afirmam que o aborto deve ter sido provocado através de descolamento progressivo das membranas envolventes do ovo, devido às injeções intra-uterinas. Apesar do exame do perito químico ter dado negativo, dizem que houve intoxicação por composto mercurial, respondendo 'sim' também ao quarto quesito. Afirmam que a saúde dela foi seriamente prejudicada, tendo mesmo corrido risco de vida. E quanto ao último quesito, declaram que há objetos capazes de provocar o aborto entre os encontrados na casa da parteira $e$ dizem que, apesar da presença dos dois embriões, não podem responder quanto à sua significação como indícios de prática anterior de aborto criminoso.

Costa Junior (1911:90-91) declara que o último quesito é um tanto inadequado, devendo ser melhor formulado, já que "objetos capazes de servir à prática do aborto são facílimos de serem encontrados, porque, maxime, atualmente, quase todos os objetos são de tal modo utilizados". Contudo, os objetos encontrados na casa da parteira devem ser considerados elementos suspeitos:

notamos a presença de objetos que servem, quer para impedir a prenhez, tais como camisas de Vênus, pessários obsturadores, esponjas preparadas, etc., quer para interromper a gravidez como sondas, hastes de laminária, centeio espigado etc., quer finalmente de fetos, de pequena 
idade, cuja origem, pela apreciação dos dados anteriores pode ser bem suspeita.

O segundo caso relatado por Costa Junior é o de F. N., casada, 37 anos, internada no serviço de clínica obstétrica do Hospital da Misericórdia em 15 de outubro de 1911. Teve dois filhos e três abortos, dos quais ela não soube explicar as causas. Estava doente há 15 dias, com febre e pulsação acelerada. No exame dos órgãos genitais foi constatada a presença de dois tampões fétidos e a existência de uma haste de laminária no colo do útero. Disse que, havia alguns dias, julgando-se doente procurou uma parteira que lhe fizera um curativo. Mas, sentindo-se pior fora procurar o hospital. A paciente foi submetida a uma curetagem e a um tratamento e ficou curada.

A terceira observação diz respeito a M. C. M., casada, 29 anos, que deu entrada também no Hospital da Misericórdia, no dia 12 de setembro de 1911. Relatou que havia oito dias tinha sofrido uma forte hemorragia, motivo pelo qual procurou uma parteira que lhe fez uma lavagem através da introdução de uma sonda uterina. Entrou em trabalho de parto e, no dia 15 do mesmo mês, expeliu um feto de quatro meses, que apresentava perfuração no tórax. A mulher faleceu no dia 10 de outubro de infecção uterina (Costa Junior, 1911:53-54).

A quarta e última observação (informações cedidas por Fernando Magalhães ao autor) refere-se à X, casada, mãe de três filhos. A doente foi examinada em um estado muito debilitado, quinze dias após a expulsão de um embrião de três meses. Confessou que havia praticado o aborto em si mesma, com a introdução de uma sonda de goma e de um abotoador de sapatos. Acrescentou que era a décima vez que assim procedia. Ela foi tratada e entrou em estado de convalescença após três meses de moléstia.

A partir do relato desses casos, Costa Junior passa a considerar os artigos do Código Penal referentes ao aborto criminoso. Explica que a inspiração do nosso Código Penal vinha da linha francesa que previa como crime de aborto toda e qualquer interrupção da gravidez, sejam quais fossem as condições de desenvolvimento e de normalidade do produto da concepção. Para o autor, seria preciso que a legislação fosse modificada em prol da proposta italiana, na qual se define o crime do aborto a partir da noção mais específica de feticídio, isto é, interrupção de uma gravidez normal com a morte do feto. O segundo e terceiro casos relatados pelo autor incorreriam nessa categoria, já que foram encontrados os fetos mor- 
tos. Nos demais, os delitos deveriam ser registrados e punidos como crimes de lesões corporais.

Costa Junior passa então a discutir o procedimento da perícia. Repete a exclamação de estranheza diante da raridade dos casos investigados pela polícia em contraste com a grande freqüência do delito na cidade. Afirma que isso se deve ao fato de que "há muitos interesses em jogo" que concorrem para tornar inaplicáveis as disposições da lei. Questiona a correção dos quesitos mencionados e insiste especialmente na distinção entre o aborto provocado e o espontâneo. Revela que o aborto natural pode ocorrer em função de traumatismos externos ou internos (neste caso podendo ser ocasionado pelo excesso do coito), da união de pais muito jovens ou muito velhos e fatigados e de casamentos consangǘneos, da predisposição das mulheres, de doenças como sífilis, tuberculose, diabetes, albuminúria, de intoxicações crônicas como o alcoolismo e o tabagismo, de infecções, da absorção de venenos, de tumores, de causas locais e de fatores ligados ao próprio ovo (moléstias e más formações). Além disso, considera também a hipótese do aborto epidêmico, devido não a uma moléstia infecciosa, mas a causas como a guerra, a fome, a miséria social etc.

Quanto ao aborto provocado, pode ser empregado em duas circunstâncias. A primeira com o fim terapêutico, sob indicação médica, a fim de salvar a vida ameaçada pela gravidez. A segunda "com o fim abjeto de simplesmente desvencilhar a mulher do seu próprio produto, sob absurdos pretextos, constituindo o aborto criminoso" (Costa Junior, 1911:79). Portanto, o motivo ou fim da provocação do aborto deve ser levado em conta pelos peritos e autoridades policiais. É preciso considerar se há circunstâncias que indicariam a interrupção da gravidez como medida terapêutica. O autor afirma que essas circunstâncias são inúmeras e bastante controversas. ${ }^{12}$ Prefere não discuti-las individualmente porque sempre haverá opiniões a favor e contra cada indicação. Porém, ressalva que, em virtude dos progressos da medicina, cada vez mais se reduz o número de casos em que realmente há necessidade de interromper a gravidez.

Costa Junior prossegue listando os meios vulgarmente utilizados para a prática do aborto, que devem ser do conhecimento do perito. Antes, observa que não está fazendo uma divulgação perniciosa desses processos, já que muitos deles são ineficazes e todos são conhecidos dos praticantes do aborto ilegal. É preciso ponderar que o próprio fato de ele fazer uma ressalva desse tipo indica que essa era uma preocupação importante para os médicos. Talvez mesmo contra a vontade, ao estudarem os meios e os 
atos praticados pelas mulheres e homens relativos ao controle da natalidade, bem como ao ampliarem o conhecimento sobre o corpo feminino e o processo de fecundação, os médicos estavam contribuindo para ampliar as técnicas de controle reprodutivo. Ao divulgarem seus estudos e, principalmente, ao se envolverem em polêmicas públicas e participarem na avaliação de casos policiais, acabavam, mesmo que de forma indireta, sendo também responsáveis pelo fenômeno que, afirmavam, tentavam combater. É claro que muitos aspectos teriam de ser considerados para uma revisão mais refinada dessa questão. Mas, o importante é enfatizar que os próprios médicos tinham alguma consciência do 'perigo' de seus trabalhos serem usados para além dos propósitos iniciais.

Tratando dos procedimentos, o autor explica que, via de regra, a mulher não lança mão de manobras diretas, mais seguras, mas que exigiriam a cumplicidade de alguém. Ela começa por empregar os meios "reputados na voz do povo" e que podem ser utilizados sem o testemunho de ninguém. Primeiramente há os abortivos que servem para auxiliar as manobras diretas: sangrias, sanguessugas, banhos, traumatismos (a partir de marchas forçadas, quedas, longas caminhadas, compressão e massagens do ventre etc.). Outro grupo é constituído pelas substâncias abortivas, como a salsa-parrilha, o aloés, a melissa, a camomila, o absinto, a canela, o café, as pílulas de Morisson, o arsênico, o fósforo, o antimônio, o mercúrio, o chumbo, o sulfato de quinina, o tabaco, o clorofórmio etc. Há também as substâncias que teriam uma ação direta no útero, como o teixo, a sabina, o zimbro, a tuia, a arruda e o centeio espigado. O terceiro grupo dos processos abortivos compõe-se das manobras diretas. São executadas sobre a vagina e o colo do útero (injeções com água morna, fria ou quente; esponjas preparadas e hastes de laminárias), o útero e o próprio conteúdo do útero (despedaçamento e punção das membranas, em geral com o auxílio de instrumentos como agulhas de tricô, hastes, sondas etc.).

O passo seguinte do autor é tratar da freqüência do aborto criminoso na cidade do Rio de Janeiro. Costa Junior (1911:94) reafirma que, apesar da pouca divulgação e repressão, os casos são muitos:

Todos sabem que, o fato de não virem à luz numerosos casos desta natureza, de modo algum significa a sua exigüidade, mas, antes a extrema prudência dos interessados, que numa verdadeira aliança andam sempre precavidos contra a divulgação dos seus crimes.

Assim, de um lado é a gestante que, para esconder uma falta, ou de 
cumplicidade ou não com o próprio marido etc., tendo recorrido a esse meio criminoso, tem todo o interesse em ocultá-lo. De outro lado, é o profissional ou não, de um ou de outro sexo, que, muitas vezes, como única testemunha, é empenhada em conservar o sigilo absoluto, não só para conservar a clientela, como para evitar complicações com a polícia.

Em seguida, o autor acrescenta que o segredo não impede que os praticantes sejam bem conhecidos e façam do aborto criminoso uma indústria rendosa. Além do mais, talvez motivados pela concorrência, têm a cada dia multiplicado os anúncios nos jornais, onde deixam claro nas entrelinhas o seu ofício. Costa Junior (1911:94-95) transcreve então alguns destes anúncios publicados nos jornais da capital:

Consultas - Mme. P... parteira e massagista, com 12 anos de prática, possui uma descoberta para senhoras doentes, que não possam ter filhos, assim como tem outros segredos particulares; garante-se ser infalível; aceita parturientes em pensão e previne à sua numerosa clientela e mais pessoas, que...

Senhoras - Médico, com especialidade estudada na Europa. Consultório... Cura radical todas as moléstias das senhoras, ovários, útero, hemorragias, corrimentos; e só evita gravidez por indicação científica (processo parisiense), sem dor nem operação. Curativos...

Consultas grátis - Médicos, especialistas, com estudos em...; evitam a gravidez por indicação científica; rua...

Mme. J. - parteira, diplomada, acaba de chegar de Paris, tendo um processo seguro para as pessoas que não possam conceber e cura...

Dr. B. G. - emprega o processo de evitar a gravidez em casos indicados, bem como cura...

Cura radical por especialista...; evita a gravidez em certos casos, por processo europeu, sem dor e sem operação; este processo é seguro, rápido, e completamente inofensivo;...

Mme. F. - tem um preparado para conceber ou não e também para a falta de regras... (Grifos e reticências do autor)

Esses anúncios são exemplos ilustrativos do recurso à imprensa. Mostram como era comum a propaganda contraceptiva e como, na visão médica traduzida nas palavras de Costa Junior, essas referências a formas de evitar a gravidez eram entendidas como prática de aborto. Em alguns casos, trata-se mesmo de médicos ou parteiras diplomadas e que chegam 
a acrescentar o adendo "indicação científica" para "prevenir" a gravidez. Como o próprio Costa Junior deixou claro anteriormente, as indicações científicas para a prática do aborto são bem variadas e, principalmente, discutíveis. Portanto, o profissional que se dispusesse a praticar abortos não teria dificuldades em alegar algum fator que pudesse ser definido como indicação científica. Mas, o fato de mencionarem essa expressão nos anúncios evidencia um cuidado com a reputação e uma prevenção a possíveis perseguições.

É preciso notar ainda que, se formal ou explicitamente esses anúncios não fazem referência ao aborto mas sim a "evitar a gravidez", e os anunciantes se vêem obrigados a adicionar a ressalva "por indicação científica", fica claro que a simples menção ao controle da natalidade seria, a princípio, mal vista. Esses exemplos levam a supor que, por um lado, a restrição ao número de filhos, seja através do aborto ou de outras práticas, era efetivamente procurada e sustentava um mercado concorrido. Por outro, isso não podia ser explicitado sem qualquer precaução. Era preciso acrescentar alguma desculpa médica para que se justificasse o trabalho do praticante e também a atitude da mulher que o procurasse. Doenças de várias ordens eram invocadas para desculpar o comportamento da mulher que não desejava ter filhos.

Os anúncios também deixam claro que os profissionais que entravam no ramo da restrição da natalidade eram os mesmos que cuidavam do bom andamento das gestações e conduziam os partos. Na prática, eram as parteiras e os ginecologistas e obstetras que detinham os segredos e ofereciam seus serviços nos jornais. As chamadas curiosas, apresentadas pelos médicos sempre de forma pejorativa em função da "falta de formação" e do envolvimento em contracepção e aborto, deviam agir através de uma rede que privilegiava o segredo e a propaganda oral. Já aqueles que anunciam nos jornais quase sempre fazem referência a algum tipo de qualificação, como 'parteira diplomada', 'especialista' ou mesmo 'médico', o que provavelmente garantia um certo respaldo perante o público. Boa parte deles também fazia referência ao estudo realizado na Europa ou a métodos importados. Ao mesmo tempo, estes profissionais qualificados provocavam a irritação da elite médica, preocupada em manter imaculada a imagem da profissão e que via como nociva a aproximação com a contracepção e o aborto. Para esses médicos, quando se tratava de acusar e combater as parteiras ou curiosas não havia maiores dificuldades. Essa luta era até mesmo 
útil na consolidação de uma imagem positiva dos médicos. Mas quando se tratava de médicos diplomados envolvidos com tais práticas, o perigo de contaminação da imagem era iminente. Parece ser muito mais grave que um profissional formado possa participar do mundo subterrâneo do controle da natalidade do que uma simples curiosa sem qualquer instrução.

Costa Junior prossegue o capítulo afirmando que a multiplicação desses praticantes só ocorre porque há uma clientela numerosa e crescente. Passa a tratar então dessa clientela e de seus motivos para recorrer ao aborto. Diz que há quem ache justificativa na atitude de pessoas da classe operária que recorrem ao aborto em função do descompasso entre o aumento da prole e o reduzido salário. Mas, há também aqueles que acreditam que o número de filhos deva ser reduzido pelo trabalho que acarretam: "não é raro ouvir dos lábios de senhoras em pleno vigor de idade e saúde, a justificativa: de que só têm um ou dois filhos, porque já são bastantes, dão muito incômodo!" (Costa Junior, 1911:96). O autor comenta que isso é simplesmente irrisório, que não há meios de a simples vontade alterar o poder procriador de uma mulher. E se ela tem poucos filhos, fatalmente se suspeita, ou mesmo se tem a certeza, de que deve se sujeitar a algum tipo de intervenção ilícita para a obtenção de tal fim.

Costa Junior (1911:96-97) define como casos curiosos aqueles em que uma mulher, especialmente sendo jovem e saudável, se desespera com mais uma gravidez e relata o seguinte exemplo:

uma ocasião, estando no consultório de um médico, ilustradíssimo e honestíssimo, à espera de nossa vez para falar-lhe, vemos sair do interior do gabinete uma senhora jovem e robusta, banhada em pranto e acompanhada do marido. A curiosidade levou-nos a indagar do motivo daquele pranto, e ouvimos, estupefatos, que aquelas lágrimas corriam, por ter o facultativo informado, após o exame, que ela se encontrava grávida, e se negando nobremente a interromper aquela gravidez, como lhe foi proposto.

Afirma que esses casos não são singulares, mas, ao contrário, bastante comuns. Para provar isso e corroborar ainda mais sua tese, realizou uma enquete entre os mais notáveis especialistas em obstetrícia da capital. As repostas, de forma oral ou escrita, foram reproduzidas integralmente pelo autor. Constituem uma valiosa contribuição sobre a prática do aborto e a visão dos médicos no começo do século XX. O primeiro relato é do professor Feijó Junior que diz, apoiado em sua longa experiência, que o 
aborto criminoso é muito freqüente no Rio de Janeiro. A maioria dos casos passa desapercebida porque as pessoas que realizam os abortos são bastante hábeis e não deixam vestígios, empregando preferencialmente o processo de ruptura das membranas.

O médico acrescenta que a impunidade é devida a dois fatores: "o primeiro é que, o médico embora conhecendo o crime e tendo mesmo nas mãos o corpo de delito, nada pode fazer, porque iria lesar o segredo profissional; o segundo é que se tal fizesse iria expor à maledicência e à irrisão do público toda uma família" (apud Costa Junior, 1911:98). Esse depoimento indica que a própria elite médica estava enredada em uma teia de segredos e compromissos, com a moralidade da profissão e com a honra das famílias de uma determinada classe, que evitava a denúncia do aborto criminoso que, supostamente, em outras condições seria feita.

A resposta seguinte é do também professor Fernando Magalhães. Informa que a prática do aborto aumenta em uma proporção assustadora. Como prova disso, conta que apenas naquele ano fora chamado doze vezes para provocar aborto sob vários pretextos, inclusive sob indicação de um outro médico. Também tratou de nove doentes em estado lastimável após a procura desse recurso. Além disso, o autor parabeniza Costa Junior pela iniciativa de propaganda contra o aborto criminoso: "O meu colega fazendo uma propaganda tenaz contra este crime sempre impune, principalmente se fixar o enorme perigo a que se expõem as mulheres que recorrem ao aborto, começará a sua vida profissional prestando um grande serviço ao indivíduo e à sociedade" (apud Costa Junior, 1911:99).

O professor Augusto Brandão diz que o número de abortos criminosos é maior do que aquele resultante dos casos de sífilis. A freqüência no Rio de Janeiro seria tão grande quanto em Paris e outras capitais, mas variadas dificuldades impediam que se apurassem devidamente os casos.

O professor Rodrigues Lima respondeu que as tentativas criminosas postas em prática no intuito de interromper a gestação eram em número avultado e constituíam um assombroso perigo para a sociedade. Na sua clínica atende freqüentemente casos de acidentes graves resultantes de aborto. Além disso, também parabeniza o serviço que Costa Junior está prestando à ciência e à humanidade e lamenta que "os clínicos nesta Capital não possuem elementos para impedir a onda crescente do charlatanismo, que desumanamente explora os infelizes clientes, que caem sob suas garras" (apud Costa Junior, 1911:100). O que impediria a 
luta dos médicos seria o sigilo guardado pelas vítimas em relação ao nome dos exploradores. Lima deixa claro uma percepção da mulher como mera vítima diante da ganância dos praticantes.

O depoimento do dr. Queiroz Barros concorda que o aborto criminoso é muito freqüente. Afirma que já prestou socorro a muitas vítimas, tendo constatado que os praticantes se dividem entre médicos, parteiras e curiosas. E espera que a tese de Costa Junior chame a atenção das autoridades para o cumprimento do seu dever.

O dr. Oliveira Motta relata que, entre outubro de 1910 e novembro de 1911, foi chamado a prestar os seus serviços em seis casos de aborto provocado criminosamente. Em quatro deles, haviam sido empregadas manobras instrumentais e nos outros dois casos, medicamentos. As seis pacientes apresentavam infecção, sendo que duas vieram a falecer. No caso de uma das mulheres, soube que já era o quarto aborto a que se sujeitava. O médico ainda informa o seguinte:

Tenho também notícia de que entre as operárias da Imprensa Nacional, há uma faiseuse d'anges muito procurada, porque injeta dentro do útero um líquido indolor e infalível. Calculou o meu informante que o número de abortos provocados por essa mulher entre o pessoal da Imprensa Nacional orça por uma centena. (apud Costa Junior, 1911:103)

Carvalho Azevedo escreve que na sua clínica tem encontrado numerosos casos de aborto criminoso, uns confessados pela doente e outros constatados através de exame. Após a intervenção cirúrgica (curetagem), as pacientes em geral melhoram, mas há casos de óbitos. Uma das pacientes que atendeu, estando já grávida, sofrera um suposto processo de esterilização através de injeções de tintura de benjoim que a levou à morte. O dr. Vieira Souto também atesta a freqüência do aborto criminoso e lamenta as dificuldades em se adotar medidas de repressão. Já Bento Ribeiro de Castro refere-se aos casos confessos que atendeu no Serviço de Obstetrícia da Maternidade do Rio de Janeiro e no Serviço de Ginecologia do Instituto de Proteção e Assistência à Infância. Instrumentos pontiagudos e beberagens tinham sido utilizados pelas parteiras curiosas ou diplomadas e mesmo por profissionais que se entregam a tal prática.

A resposta do dr. Arnaldo Quintella começa parabenizando o autor da tese pela escolha do tema extremamente importante, já que marca uma época de desmembramento social. Constata que o aborto criminoso vem 
imperando assustadoramente no Rio de Janeiro e transforma-se a cada dia em um comércio crescente de perniciosas conseqüências. Em abril do mesmo ano, Quintella tinha apelado à classe médica presente na sessão solene de comemoração do $25^{\circledR}$ aniversário da Sociedade de Medicina e Cirurgia que era imprescindível a profilaxia contra a prática despudorada do aborto criminoso. E acrescenta, realçando as conseqüências para a 'despopulação' do país: "A despopulação do País sofre deste ofício desumano, um duplo golpe: a destruição do embrião e, muitas vezes, a morte da progenitora, arrebatada, por infeç̧ão que lhes ocasionam os infanticidas profissionais, quase sempre ignorantes dos preceitos de higiene" (apud Costa Junior, 1911:104-105). Vale notar que Quintella chama de infanticidas os praticantes de aborto, evidenciando uma percepção de continuidade entre os crimes do aborto e infanticídio. Transcrevo o trecho final do depoimento no qual aparece a idéia de uma empreitada moral a ser encampada pelos médicos, perseguindo os praticantes de aborto criminoso e orientando as débeis gestantes:

É indispensável, meu colega, que as novas gerações médicas cerrem fileiras contra semelhante abastardamento de tão momentosa fase moral. Não é raro nos consultórios dos especialistas obstetras, a proposta da interrupção da gravidez pelos interessados no crime. Nada menos de três casos, neste gênero, me apareceram no mês findo.

Assim precisamos não esmorecer na campanha de regeneração destes hábitos. Ela será fatalmente vencedora no dia em que a majestade da lei punir sem piedade os personagens desta função abjeta. Ao lado disso, cumpre amparar por conselhos reiterados, a debilidade moral das gestantes inconscientes. (apud Costa Junior, 1911:105-106)

O único depoimento que destoa dos apresentados é o do dr. Erico Coelho. Este médico discorda que o aborto criminoso seja muito freqüente no Rio de Janeiro. Coelho é da opinião de que:

ao passo que o aborto criminoso na Europa é a regra, entre nós é a exceção, é pouco freqüente; que isto é devido à uma questão de raça, influída pela paz, pela tranqüilidade da guerra, pois que a mulher faz guerra à guerra; que a facilidade da vida entre nós concorre poderosamente para que a mulher não evite a gravidez, o que, pelo contrário, acontece nos países europeus. (apud Costa Junior, 1911:101)

A posição singular de Erico Coelho não é comentada por Costa Junior. Este último apenas se contenta em dizer que essa foi a única opinião 
dissonante. Todas as outras corroboraram a sua tese de que o aborto criminoso é muito freqüente no Rio de Janeiro, exigindo dessa forma a tomada de providências. É exatamente a respeito disso que continua o seu trabalho, com o capítulo final intitulado 'Profilaxia'. Costa Junior (1911:112) começa lembrando as conseqüências funestas do aborto criminoso para o indivíduo e a sociedade. No primeiro caso, fala do perigo que representa para a saúde das mulheres. No segundo, explica que o aborto "é um crime eminentemente anti-social, pois destrói a sociedade, sacrificando o indivíduo". As conseqüências são a degradação moral e a diminuição da população. Lastima especialmente esta última em função de o país ter um território tão vasto para povoar, necessitando de habitantes, principalmente de 'brasileiros'. Adverte que um fato semelhante já alarmou o governo francês e provocou a adoção de medidas, o que também deveria acontecer no Brasil. Segundo o autor:

Assim como o governo adota medidas profiláticas contra a peste, a varíola, o cólera, deveria igualmente estabelecer medidas, que, ao menos, fizessem decrescer (pois que a extinção seria talvez impossível) a cifra deste crime abominável, que dando farta renda a um número de pouco escrupulosos, reduz a nossa população, sacrificando os novos produtos humanos, e às vezes, mesmo o próprio elemento materno. (Costa Junior, 1911:113)

A luta teria de se iniciar contra a classe de indivíduos que praticam o crime através de uma campanha tenaz e implacável que certamente reduziria o número dos "mercadejadores desta indústria aviltante". Nessa luta, estaria implicada uma série de medidas. A primeira é a alteração da interpretação do segredo profissional. Assim como é obrigado a comunicar um caso de peste ou de varíola, o médico deveria também comunicar à polícia os casos de aborto criminoso, não deixando de fazê-lo sob a desculpa do segredo. A segunda medida se refere à regularização e fiscalização das funções e atribuições das parteiras, pois essas constituiriam o maior contingente de praticantes do aborto criminoso. Se uma fiscalização efetiva mantivesse as parteiras dentro das suas atribuições e impedisse que adentrassem no terreno do médico, fazendo trabalhos de ginecologia, as chances de realização de aborto diminuiriam. A terceira medida diz respeito ao aumento da penalidade dos criminosos, que agiria amedrontando os praticantes. Esta modificação só teria validade se fosse de fato colocada na prática, o que não acontece com as disposições do Código Penal em vigor. 
E a última providência consiste na realização do inquérito policial em segredo, o que concorreria para que muitos profissionais, deixando de lado a piedade pelos criminosos que seriam difamados por comentários desagradáveis, comunicassem os fatos à polícia.

Todas essas medidas sugeridas por Costa Junior se propõem exclusivamente a facilitar a repressão ao crime do aborto. Embora a proposta fosse de profilaxia, nenhuma medida de prevenção de ordem social ou mesmo moral é apresentada. O autor ainda solicita que a lei existente seja colocada em prática. E termina o trabalho com a seguinte passagem, que relaciona o crime do aborto à moral pública, à probidade profissional e ao futuro do país:

A nós, talvez iludidos ainda pela inexperiência profissional, parece que a ação simultânea destes vários fatores, seria coroada pelo êxito ambicionado, de ver esta indústria abjeta, bem reprimida, em benefício da nossa Moral Pública e da probidade profissional tão decadentes, e do nosso País que necessita de seus filhos para atingir rapidamente o glorioso futuro, a que está destinado. (Costa Junior, 1911:117)

De todo o extenso trabalho de Costa Junior vale reter alguns elementos. O primeiro, bem ilustrado pelo trecho citado, consiste na preocupação evidenciada pelos médicos com questões bastante amplas como a moralidade pública e o futuro do país. Temas como o do aborto criminoso colocam em evidência que os médicos efetivamente pretendiam examinar e tratar da sociedade como um todo e não apenas dos indivíduos. Costa Junior, por exemplo, parece menos preocupado com as formas de tratamento das conseqüências do aborto ou com especificidades médico-legais do que com a perseguição dos praticantes, pretendendo intervir diretamente no terreno da justiça e da polícia. E, em última instância, o aborto é considerado nocivo porque prejudica a sociedade, usurpando-lhe mais um indivíduo, ou o país, restringindo o crescimento da população, impedindo o progresso e colocando em risco a soberania da nação.

Outro ponto importante se refere ao fato de que Costa Junior concentra seus argumentos em torno dos praticantes do aborto, e não da mulher que a ele recorre. É certo que, em algumas passagens, condena estas muIheres e desqualifica todos os seus motivos. Mas elas aparecem mais como vítimas da ganância dos praticantes, da degradação dos costumes e da sua própria debilidade moral. A mulher é descrita como menos responsável. O peso maior, as acusações e as medidas profiláticas dizem respeito aos 
médicos, parteiras ou curiosas que se prestam às manobras abortivas. ${ }^{13} \mathrm{De}$ fato, do ponto de vista de um discurso médico elitista e normativo, desresponsabilizar as mulheres, acentuando a culpa dos praticantes, seria estratégico. Por um lado, demarca bem o terreno das práticas consideradas impróprias para profissionais da área obstétrica e ginecológica, separando os médicos de moral ilibada dos praticantes desqualificados. Por outro, o pouco destaque dado aos motivos que levam as mulheres a recorrer ao aborto poderia ser interpretado como uma forma de negligenciar, esconder e atenuar a constatação da intenção de controle da natalidade.

Sair do plano das causas genéricas como a 'degradação moral dos costumes' e especificar as razões das mulheres, muitas vezes acompanhadas de maridos e companheiros nas suas atitudes, implicaria explicitar que a maternidade nem sempre era desejada e imperiosa, como queriam muitos médicos. Parece mais interessante, para quem advoga a restrição dos papéis femininos ao cuidado com os filhos, a desqualificação da vontade individual feminina e a conseqüente rotulação das mulheres como vítimas. No mesmo sentido, os praticantes do aborto e incentivadores de métodos contraceptivos são sempre descritos como aproveitadores, mercantilistas, gananciosos, imorais. Não se cogita que suas atitudes estivessem respaldadas em convicções morais, sociais ou políticas.

A tese de Archimino M. de Mattos defendida em 1923 traz contribuições interessantes para a discussão. $\mathrm{O}$ autor introduz o tema falando da frouxidão das leis do país e da repressão policial. Confessa que ainda não existiam estatísticas sobre este "problema social tão grave", mas que, por meio de conversas com médicos e da leitura de anúncios em jornais, não tinha dúvidas sobre a proliferação do aborto criminoso. Acrescenta que este era um crime próprio das sociedades em decadência. E cita cálculos de Afranio Peixoto provando que o aborto custa muito caro à nação, já que cada vida humana tem um valor apreciável. Contudo, o aspecto mais interessante do trabalho se refere aos casos citados, considerando os motivos que levaram às tentativas de interrupção da gravidez.

O primeiro caso ocorreu no ano de 1917, quando Mattos trabalhava como farmacêutico e foi procurado por uma senhora de suas relações, para que lhe desse um remédio que fizesse reaparecer-lhe as regras. Declara que "apesar das evasivas e dos circunlóquios empregados", chegou à conclusão de que era solicitado a praticar um aborto (Mattos, 1923:13). Diz ainda que também com evasivas se recusou a dar o remédio, aconselhando à cliente a procurar um médico. Ela preferiu se valer dos serviços de uma 
comadre no bairro do Riachuelo. Com beberagens e outras práticas, após cerca de 15 dias, foi atacada de uma forte hemorragia, e se não fosse o auxílio de um médico chamado às pressas teria perdido a vida.

O segundo caso é relatado da seguinte forma:

De outra feita, fomos procurados por A., português de 25 anos, que nos pediu claramente um remédio para provocar em M., rapariga mulata com quem entretinha relações amorosas, um desmancho.

Foi nosso primeiro movimento o de recusarmos; dada a firmeza da solicitação, adquirimos a certeza de que, se não fizéssemos outro o faria. Aceitamos, portanto, a incumbência.

Prescrevemos para a rapariga uma garrafa de um vinho tônico de Granado, a que tiramos previamente o rótulo e exigimos que ele fosse dado com toda a regularidade.

Ao cabo da primeira garrafa, procurou-nos novamente o português, meio zangado já, porque o remédio não fazia efeito.

Convencemo-lo ser fraca a dose e repetimos a prescrição com a recomendação de ser tomado o dobro da dosagem primitiva.

Assim ganhamos tempo e salvamos uma vida ameaçada por um pai desnaturado. (Mattos, 1923:13-14. Grifo do autor)

O terceiro caso se refere a uma senhora casada do Engenho de Dentro que, após o terceiro filho, aprendera a usar lavagens vaginais depois do coito para evitar a gravidez. Mas, em uma noite esquecera de assim proceder e engravidara. Solicitou ao autor que praticasse um aborto. Este apelou para os seus sentimentos maternos e, após alguns dias de insistência dela, ameaçou denunciá-la à polícia.

A respeito desses casos, Mattos faz o seguinte comentário:

Destas, a primeira senhora, que tivera apenas dois filhos, com o marido constantemente ausente e de hábitos de coquette, não queria ter mais filhos para não envelhecer depressa; a segunda era positivamente um caso de sedução, cujas provas se tornavam necessárias desfazer; e a terceira procurava o aborto para evitar a instrução e educação do filho, dados os seus poucos recursos.

São os casos mais freqüentes, além daqueles em que é praticado o aborto para evitar o repúdio da família, a notoriedade entre pessoas de relações ou ainda, vários, para se vingar do sedutor. 
No primeiro caso, a profilaxia deve ser mais moral que repressiva, educando-se a mulher desde menina, a encarar a maternidade como um encargo natural e elevado, educação vinda, já pelo lar, pela escola, pelos púlpitos, pela imprensa, pelo livro. (Mattos, 1923:14-15)

De uma maneira distinta de Costa Junior, Mattos focaliza as situações pessoais que levam à prática do aborto. Deixa claro desta forma que na prática cotidiana dos profissionais de saúde era comum a solicitação da interrupção da gravidez por motivos que variavam bastante, refletindo contextos sociais e econômicos diferenciados. Enquanto a primeira mulher é apresentada como tendo posses e recorrendo ao aborto por motivos fúteis, a terceira temia a falta de condições de educar mais um filho. Já no segundo caso, é interessante que o próprio 'sedutor' é quem vai procurar uma solução. O procedimento de Mattos neste caso, enganando o cliente, é revelador das atitudes que poderiam ser tomadas pelo médico tendo como base a sua autoridade científica e principalmente moral.

O autor exemplifica que havia uma demanda por métodos de controle da natalidade para a qual os médicos deveriam fornecer respostas. Alguns atendiam os desejos e necessidades das clientes que os procuravam. Outros, como o próprio Mattos, respondiam pelo repúdio a tal atitude e pela elaboração de uma proposta profilática. Nesse caso, profilaxia tem o sentido de prevenção moral, através da educação da mulher desde menina para a aceitação da maternidade como um encargo natural. Além disso, o autor também adiciona que deve haver um programa de proteção às crianças filhas de pais desconhecidos e mães sem recursos, já que é notório que o fator econômico é a mais eloqüente causa de aborto criminoso. A repressão à sedução de menores também é cogitada. A tese de Mattos parece reconhecer que o aborto é praticado não apenas em função de uma degradação moral dos costumes ou da oferta dos praticantes interessados em ganhar dinheiro, como enfatiza Costa Junior, mas a partir de intenções refletidas, articuladas racionalmente pelas mulheres, ou por alguns homens, diante de determinadas conjunturas. Entretanto, mesmo concebendo esse caráter racional da atitude das mulheres, Mattos termina por identificar aí também um problema a ser combatido com o reforço da educação para a maternidade e com a proteção de filhos e mães sem recursos.

Em um manual de obstetrícia publicado originalmente em 1924, Arnaldo de Moraes (1937:420-421) também considerava a questão do aborto provocado na cidade do Rio de Janeiro. Afirmava em primeiro lugar 
que o aborto criminoso era cometido "sem a menor sombra de pudor, às escancaras das autoridades a quem cumpre a defesa da lei e o impedimento do crime, por pessoas leigas, 'curiosas', parteiras e médicos!". E propunha que a tarefa dos médicos não era delatar, mas contribuir para o fim deste flagelo social, esclarecendo sobre os riscos que representava para as mulheres, bem como sobre os prejuízos para coletividade. Além disso, no trecho que segue, vemos ainda a justaposição de uma perspectiva de profilaxia social e de repressão e também de ênfase no indivíduo (as pacientes) e na sociedade (a pátria, os costumes):

Ao médico, no exercício de sua profissão, não cumpre delatar esses crimes, mas cabe-lhe o papel social de fazer a profilaxia do mal pela divulgação do perigo a que as pacientes se expõem (mortalidade $e$ morbidade principalmente), lembrando aos poderes públicos os prejuízos para a pátria (diminuição da natalidade) e para os costumes (imoralidade), e, perseguindo de todos os modos os 'profissionais do crime', excluindo-os da sua convivência. (Moraes, 1937:421)

Gostaria de chamar a atenção para o fato de que, nas discussões envolvendo aborto e contracepção, temos ilustrado o movimento de ampliação da medicina para o tratamento de questões mais abrangentes. São em particular os ginecologistas e obstetras que se dedicam a esses temas. Tais especialistas se definiam como os mais capazes para delimitar, entre outras coisas, o terreno do que era permitido ou não em relação a aborto e contracepção. No que se refere ao aborto criminoso, são os principais personagens envolvidos em polêmicas e debates públicos. O problema 'social' representado pelo aborto era também da sua alçada. Estava no domínio das perturbações relativas ao comportamento feminino e à sexualidade e reprodução.

Já vimos que estas perturbações podem assumir a forma da loucura puerperal, por exemplo. Nessas situações, os problemas de origem genital causam desordens mentais, chegando mesmo a suprimir a consciência das 'doentes'. ${ }^{14}$ No caso do aborto criminoso e contracepção, já não é possível associar o ato cometido com uma desordem mental. Ao contrário da infanticida, praticamente uma louca temporária, a mulher que comete um aborto é, pelo menos a princípio, considerada uma 'criminosa' plenamente ciente dos seus atos. Mas o interessante é que, em ambos os eventos, a conseqüência mais destacada pelos médicos é a lesão da sociedade, ou da nação, na medida em que se suprime um futuro cidadão. Outra semelhança 
é o fato de que tanto a mulher que comete infanticídio quanto a que comete aborto representam o 'perigo', do ponto de vista de boa parte dos médicos, da disjunção entre sexo, reprodução e maternidade. No caso das infanticidas, a ameaça é expressa no caráter de excepcionalidade que recobre o crime e que praticamente pressupõe que não há mãe que, conscientemente, possa querer matar o próprio filho.

No caso das mulheres que recorrem ao aborto e à contracepção, já não é mais possível invocar uma falta de consciência, uma loucura temporária. O fato de quererem impedir novas gestações e novos filhos é explicitado de diversas formas, bastante evidentes. Contudo, o que vimos é como os médicos raramente 'acusam' as mulheres, preferindo pôr a 'cul$\mathrm{pa}^{\prime}$ pelos abortos, por exemplo, nos profissionais praticantes ou então citando elementos tão ambíguos e genéricos como a 'devassidão dos costumes'. Há uma tentativa, pelo menos por parte de alguns, de se recusar a perceber e a divulgar a intenção de controle da natalidade e o desejo de manter relações sexuais sem uma gravidez subseqüente, o que era demonstrado por um grande número de mulheres - e também de homens.

Outro ponto que merece ser destacado no que diz respeito ao aborto provocado é o tipo de 'solução' prevista pelos médicos, que se insere em um projeto de profilaxia social, uma estratégia mais abrangente e condizente com a natureza social do problema. Em um contexto político no qual a população adquiria cada vez mais importância, os médicos vão investir menos no 'tratamento' individual e mais em campanhas de condenação do aborto e da contracepção e de valorização da maternidade. O argumento invocado passava pelo perigo que estas práticas representariam em termos de comprometer o projeto nacional de construção de um povo numeroso e 'saudável'.

\section{Notas}

1 Como veremos nos próximos capítulos, essa concepção presente no discurso médico nem sempre correspondia ao que aparece nos depoimentos de outros personagens. Nos processos contra os crimes de aborto e infanticídio, há evocações dessas práticas não como sintomas de loucura, mas como alguns dos parcos meios de controle da natalidade de que dispunham as mulheres. É preciso lembrar também que a valorização da criança, especialmente nos primeiros dias de vida e em situações em que não teria muitas chances de desenvolvimento, é um processo cultural e histórico, como 
demonstrou Ariès (1973).

2 No manual de obstetrícia editado por Rezende (1998), vemos que o puerpério continua sendo considerado por muitos médicos como o período de maior suscetibilidade da mulher aos distúrbios mentais. Hoirisch (1998:479) chega a afirmar que: "Não se pode delimitar com precisão onde acabam as manifestações de uma adaptação normal à gestação e ao puerpério e onde começam sintomas de psiconeurose, organoneurose ou psicose." O próprio Rezende (1998), ao tratar dos "Aspectos médico-legais e éticos da obstetrícia", comenta que se alude à influência do estado puerperal nos casos de infanticídio, o que deve ser cuidadosamente analisado pelos peritos em cada caso.

3 As teses sobre infanticídio catalogadas são: Neves (1839), Castro (1852), Oliveira (1852), Bittencourt (1853), Sequeira (1852), Pessoa Filho (1861), Machado (1885), Silva (1887), Silva (1888), Fonseca (1889), Jorge (1889), Maranhão (1890), Barros (1890), Monteclaro (1890), Barcellos (1892), Pacheco (1893), Lopes Filho (1894), Oliveira (1898).

4 Ver os seguintes trabalhos: Pegadus (1877), Franco (1877), Lopes (1877), Oliveira (1882), Araujo (1883), Azevedo (1919), Post (1925) e Gomes (1927).

5 Ver Moreira (1873), Bettamio (1874), Camara (1898), Antunes (1907), Campos (1910), Costa Junior (1911), Pimentel (1917), Mattos (1923) e Rizzo (1925).

6 O recurso às legislações estrangeiras é uma estratégia comum empregada pelos médicos de modo a validar ou questionar as leis brasileiras. Este método é utilizado, entre outros, por Cruz Machado em 1885 e Araujo Jorge em 1889.

7 Ver, por exemplo, os seguintes trabalhos: Abreu (1851), Santos (1858), Vilhena Junior (1859), Dias (1872), Romeiro (1885), Pires (1892), Neri (1899), Ribeiro (1906), Bustamante (1906), Moraes Filhos (1906), Azevedo (1910), Rocha (1910), Carvalho (1914), Daviloff (1916), Sebas (1917), Enout (1917), Silva (1922), Tatsch (1922), Cavalcanti (1925), Sucupira (1926).

8 A partir do fim do sexto mês, passa-se a falar em "parto prematuro provocado" (Costa Junior, 1911:73).

9 Em 1869, o papa Pio IX aboliu a distinção entre feto animado e inanimado, admitindo que $o$ aborto em qualquer fase da gravidez tinha a mesma gravidade e passava a ter a mesma punição, que era a excomunhão (Thiollier, 1983). Para uma cronologia das mudanças de posição da Igreja com relação ao aborto, ver o artigo "Abortion and catholic thought" na revista Conscience (1996).

* Este rápido exemplo, dado por Magalhães, das disputas entre medicina e Igreja aponta para um jogo bastante complexo de relações que passava sobretudo pela discussão em torno de quem tinha mais autoridade para definir as regras sociais em terrenos delicados como o da reprodução. Para uma visão mais geral sobre este ponto, ver o trabalho de Borges (1991).

1 Nem todos concordavam com Magalhães. Souza Lima, especialista em medicina legal, não admitia que o médico pudesse escolher que vida salvar. Usa como argumento o fato de que a mulher poderia valer "sociologicamente" menos do que o produto da concepção. Se cumprisse a sua missão de dar à luz, ela não teria mais tanto valor assim: "Quantas vezes um pequeno ser acanhado, enfezado ou raquítico, poderá vir a ser um homem notável e célebre por qualquer título, um varão assina- 
lado em qualquer dos ramos da atividade humana? Quantas vezes a mulher vale, sociologicamente, menos do que o produto de sua concepção?" (Souza Lima, 1933:769).

n Costa Junior cita o vômito incoercível, a anemia perniciosa, as moléstias do coração, os tumores cerebrais, as nevrites gravídicas, as pielo-nefrites, a tuberculose renal, a albuminúria periódica e algumas de suas complicações, como as perturbações graves da vista, a eclâmpsia, os vícios pelvianos (bacias raquíticas e osteomalácicas, cifose, escoliose, bacias viciadas por paralisia infantil ou por fraturas etc.), o câncer uterino, a placenta prévia, a endometrite decidual, a mola hidatiforme, o hidramnios agudo, a tuberculose pulmonar, a nefrite grave etc.

13 Le Mée (1986), a partir do estudo do caso de julgamento de uma aborteira em Paris em 1890, menciona que também naquele contexto o aborto era percebido como um crime perdoável para a mulher mas não para o praticante, seja ele médico ou parteira ou leigo.

14 Sobre a insistente conexão entre órgãos genitais e perturbações mentais na mulher, ver Rohden (2001a) e Groneman (2001) 